\title{
Role of quilting technique of mastectomy flap in prevention and reduction of seroma complication in breast cancer patients.
}

\author{
Mohend A. N. Al-Shalah* \\ Department of Surgery, College of Medicine, University of Babylon, Hilla, Iraq
}

\begin{abstract}
Objective: The aim of study is to evaluate effectiveness of quilting or tacking mastectomy flap in preventing or reducing seroma formation.

Methods: Study included patients with diagnosed breast cancer. Mastectomy with axillary clearance surgery was done for them. Patients were divided according to the technique of closure of mastectomy flap in to quilting and non-quilting group. Primary outcome were the presence of seroma complication and the amount of fluid collection that require aspiration. Secondary outcome were the mean differences of fluid drained, time to remove drain, stage of disease, level of axillary clearance, distribution of patients according to type of malignancy, oestrogen, progesterone and Her2/Neu receptor status.

Results: Results of the study showed that there was a significant association between type of operation and presence of seroma, more seroma occur among patients treated with non-quilting technique $(\mathbf{4 6 . 8 \% )}$ in comparison to quilting technique (20\%) (P value 0.012$)$ and more time needed to remove drain among patients treated with Non-quilting technique (with mean $5.74 \mathrm{~d}$ ) in comparison to quilting technique (with mean $4.74 \mathrm{~d}$ ). There were significant differences between means of amount of aspiration among patients with seroma $(\mathrm{n}=\mathbf{2 9})$ by study groups, more amount of aspiration among patients treated with non-quilting technique (with mean $144.54 \mathrm{ml}$ ) in comparison to quilting technique (with mean $60.71 \mathrm{ml}$ ). Conclusion: Quilting or tacking mastectomy flap to the underlying muscles and fascia to obliterate the surgical dead space is effectiveness in prevention and reduction of seroma formation.
\end{abstract}

Keywords: Breast cancer, Mastectomy flap, Quilting technique.

Accepted on April 23, 2018

\section{Introduction}

Breast cancer is a widespread cancer among women and comprising $23 \%$ of female cancers [1]. Since 1990s, breast cancer rates have increased, and at the same time survival rates have improved due to early diagnosis by breast cancer screening program, and effectiveness of variable treatment modality [1-3]. In Iraq, breast cancer is the most common type of female cancer and representing $33 \%$ of the all-female cancer patients [4]. One of the commonest early sequels of breast cancer management is seroma formation which is defined as a collection of serous fluid in the dead space of post-mastectomy skin flap, axilla [5].

Seroma remains an unresolved problem post-mastectomy which lead to elevation of the flaps from the chest wall and axilla there by preventing their adherence to the underlying fascia and muscles which in turn lead to delayed wound healing, infected wound due to repeated aspiration, wound dehiscence, prolonged hospitalization, and delay of adjuvant chemotherapy [6]. In practice, several techniques have been reported to prevent or decrease seroma formation such as meticulous techniques of breast surgery using electro cautery, ultrasonic dissection and Argon enhanced electro- surgery may reduce the incidence of seroma formation on the expense of obvious cost implications for harmonic scalpel and Argon beam coagulation, use of sealants and sclerotherapy such as fibrin glue, external compression dressing to the chest wall and axilla to obliterate the dead space, use of drains and delayed shoulder exercise [7-11]. There are inconsistent and uncertain outcomes on the beneficial role of these techniques in preventing seroma formation. The aim of this study is to evaluate effectiveness of quilting or tacking mastectomy flap to the underlying muscles and fascia to obliterate the surgical dead space by interrupted absorbable suturing in preventing or reducing seroma formation.

\section{Materials and Methods}

\section{Study design}

This prospective cohort study was carried out in a Hilla General Teaching Hospital and Babylon Private Hospitals, Iraq. During the study period between December 2010 and December 2016, 82 patients with diagnosed breast cancer and agreed to do mastectomy with axillary clearance surgery were included in this study. 


\section{Study population and ethical standards applied}

Patients with diagnosed breast cancer between December 2010 and December 2016 and agreed to do mastectomy with axillary clearance surgery were included in this study. Sociodemographic characteristics which include age, BMI, smoking history and family history of breast cancer were taken from all patients. Data were collected on the day of surgery and at an outpatient follow up two weeks postoperatively. All procedures followed in this study were in accordance with the ethical standards of the responsible committee on human experimentation (Institutional and National) and with the Helsinki Declaration of 1975, as revised in 2008.

Surgery was done for all patients by the same surgical team in which simple mastectomy with the preservation of pectoralis muscle and fascia. Axillary clearance was done for all patients and level of clearance identified and registered for each. Patients were divided in two groups according to the technique of closure of mastectomy flap. Non-quilting technique was done to the first group of patients between December 2010 till January 2014 and the quilting technique was done for second group of patient's in-between February 2014 till December 2016. In the non-quilting technique, two Redivac drain were left, one in the axilla and the other underneath mastectomy flap. The skin edge after mastectomy was approximated with $2 / 0$ vicryl suture and closed subcutically using 0 nylon suture.

In the quilting technique, after mastectomy and axillary clearance completion, multiple interrupted sutures were taken starting in the lower flap from medial to lateral between the mastectomy flap and underlying pectoralis muscle and fascia tacking between them using $2 / 0$ vicryl suture to obliterate the dead space underneath the mastectomy flap with care to avoid dimpling of the dermis. The second row was done by the same interrupted suture from lateral to medial till the medial angle. The same was done for the upper flap.

Redivac drain was left only in the axilla and no drain left underneath the flap. The skin edge after mastectomy were approximated with $2 / 0$ vicryl suture and closed subcutically using 0 nylon suture. Data were collected on the subsequent 14 d postoperatively. Primary outcome were the presence of Seroma complication and the amount of fluid collection that require aspiration. Secondary outcome were the mean differences of fluid drained by the drainage system, time to remove drain, stage of disease, level of axillary clearance, distribution of patients according to type of malignancy, oestrogen receptor, progesterone receptor and Her2/Neu receptor status.

This study had been acknowledged by College of Medicine University of Babylon and authorized by Babylon health directorate/Babylon General Teaching Hospital. All patients had been consented and agreed to participate in this study.

\section{Data analysis}

Statistical analysis was carried out using SPSS version 20. Continuous variables were presented as (Means \pm SD). Student t-test was used to compare means between two groups. Categorical variables were presented as frequencies and percentages. Pearson's chi square $\left(\mathrm{X}^{2}\right)$ and Fisher-Exact test were used to find the association between categorical variables. A p-value of $\leq 0.05$ was considered as significant.

\section{Results}

Regarding distribution of patients according to sociodemographic characteristics, result show that the mean age of patients were $47.01 \pm 10.17 \mathrm{y}, 47.6 \%$ of breast cancer patients were overweight and $32.9 \%$ were in the obese range, $26.8 \%$ of breast cancer patients were smoker and there were $13.4 \%$ of breast cancer patients had positive family history as shown in Table 1. Regarding distribution of patients according to type of malignancy, result found that the majority $(84.1 \%)$ of patients presented with Invasive ductal carcinoma, (9.8\%) invasive lobular carcinoma and (6.1\%) inflammatory type.

Table 1. Distribution of patients according to socio-demographic characteristics.

\begin{tabular}{lll}
\hline \multicolumn{2}{l}{ Socio-demographic characteristics } & \\
\hline Age & $47.01 \pm 10.17$ & $28-72$ \\
\hline BMI & & 0.195 \\
\hline Normal (18.5-24.9) & 16 & 0.476 \\
\hline Overweight (25-29.9) & 39 & 0.329 \\
\hline Obese ( $\geq 30)$ & 27 & 1 \\
\hline Total & 82 & 0.268 \\
\hline Smoking & & 0.732 \\
\hline Present & 22 & 1 \\
\hline Absent & 60 & 1 \\
\hline Total & 82 & 0.134 \\
\hline Family history & 11 & 0.866 \\
\hline Present & 71 & \\
\hline Absent & 82 & \\
\hline Total & & \\
\hline & & \\
\hline
\end{tabular}

Results of association between type of operation and study variable including (seroma required drainage, Oestrogen receptor, progesterone receptor, Her2/Neu receptor), found that there was significant association between type of operation and presence of seroma. More seroma occur among patients treated with non-quilting technique $(46.8 \%)$ in comparison to quilting technique $(20 \%)$ as shown in Table 2.

Table 2. Association between type of operation and study variables.

\begin{tabular}{|c|c|c|c|c|c|}
\hline \multirow{2}{*}{$\begin{array}{l}\text { Study } \\
\text { variables }\end{array}$} & \multicolumn{3}{|c|}{ Type of operation } & \multirow[t]{2}{*}{$x^{2}$} & \multirow[b]{2}{*}{ P-value } \\
\hline & $\begin{array}{l}\text { Non } \\
\text { technique }\end{array}$ & quilting & $\begin{array}{l}\text { Quilting } \\
\text { technique }\end{array}$ & & \\
\hline
\end{tabular}


Role of quilting technique of mastectomy flap in prevention and reduction of seroma complication in breast cancer patients

\begin{tabular}{|c|c|c|c|c|}
\hline \multicolumn{5}{|l|}{ Seroma } \\
\hline Present & $22(46.8)$ & $7(20.0)$ & \multirow{3}{*}{6.307} & \multirow{3}{*}{$0.012^{*}$} \\
\hline Absent & $25(53.2)$ & $28(80.0)$ & & \\
\hline Total & $47(100.0)$ & $35(100.0)$ & & \\
\hline \multicolumn{5}{|c|}{ Oestrogen receptor } \\
\hline Positive & $34(72.3)$ & $26(74.3)$ & \multirow{3}{*}{0.039} & \multirow{3}{*}{0.844} \\
\hline Negative & $13(27.7)$ & $9(25.7)$ & & \\
\hline Total & $47(100.0)$ & $35(100.0)$ & & \\
\hline \multicolumn{5}{|c|}{ Progesterone receptor } \\
\hline Positive & $32(68.1)$ & $21(60.0)$ & \multirow{3}{*}{0.574} & \multirow{3}{*}{0.449} \\
\hline Negative & 15 (31.9) & $14(40.0)$ & & \\
\hline Total & $47(100.0)$ & $35(100.0)$ & & \\
\hline \multicolumn{5}{|c|}{ Her2/Neu receptor } \\
\hline Positive & $17(36.2)$ & $18(51.4)$ & \multirow{3}{*}{1.909} & \multirow{3}{*}{0.167} \\
\hline Negative & $30(63.8)$ & $17(48.6)$ & & \\
\hline Total & $47(100.0)$ & $35(100.0)$ & & \\
\hline
\end{tabular}

Table 3. Mean differences of drainage amount, time to remove drain and aspiration amount according to type of operation.

\begin{tabular}{|c|c|c|c|c|c|}
\hline $\begin{array}{l}\text { Study } \\
\text { variable }\end{array}$ & Type of operation & $\mathbf{N}$ & Mean & t-test & $P$ value \\
\hline \multirow{2}{*}{$\begin{array}{l}\text { Amount of } \\
\text { drainage }(\mathrm{ml})\end{array}$} & $\begin{array}{l}\text { Non } \\
\text { technique }\end{array}$ & 47 & $\begin{array}{l}522.98 \\
166.19\end{array}$ & \multirow{2}{*}{0.677} & \multirow{2}{*}{0.501} \\
\hline & Quilting technique & 35 & $\begin{array}{l}494.86 \\
210.21\end{array}$ & & \\
\hline \multirow{2}{*}{$\begin{array}{l}\text { Time for drain } \\
\text { removal (d) }\end{array}$} & $\begin{array}{l}\text { Non } \\
\text { technique }\end{array}$ & 47 & $5.74 \pm 1.25$ & \multirow[t]{2}{*}{3.79} & \multirow[t]{2}{*}{$<0.001^{*}$} \\
\hline & Quilting technique & 35 & $4.74 \pm 1.06$ & & \\
\hline \multirow{2}{*}{$\begin{array}{l}\text { Amount of } \\
\text { seroma that } \\
\text { require } \\
\text { aspiration }(\mathrm{ml})\end{array}$} & $\begin{array}{l}\text { Non } \\
\text { technique }\end{array}$ & 22 & $144.54 \pm 86.66$ & \multirow[t]{2}{*}{4.37} & \multirow[t]{2}{*}{$<0.001^{*}$} \\
\hline & Quilting technique & 7 & $60.71 \pm 13.36$ & & \\
\hline
\end{tabular}

Regarding the mean differences of amount of drainage by tube drain, time to remove drain and amount of seroma that require aspiration according to type of operation, results found that there were significant differences between means of time need to drain remove by study groups, more time needed to remove drain among patients treated with Non quilting technique (with mean $5.74 \mathrm{~d}$ ) in comparison to quilting technique (with mean $4.74 \mathrm{~d}$ ). There were significant differences between means of amount of aspiration among patients with seroma $(n=29)$ by study groups, more amount of aspiration among patients treated with non-quilting technique (with mean $144.54 \mathrm{ml}$ ) in comparison to quilting technique (with mean $60.71 \mathrm{ml}$ ) as shown in Table 3.

Study also showed significant association between presence of seroma and BMI and level of axillary clearance in which, more seroma occur among obese patients $(65.5 \%)$ and more seroma with increasing level of clearance. There were insignificant association between presence of seroma with smoking, and family history as shown in Table 4.

Table 4. Association between presence of seroma and study variables.

\begin{tabular}{|c|c|c|c|c|}
\hline \multirow{2}{*}{ Study variables } & \multicolumn{2}{|c|}{ Presence of seroma } & \multirow[t]{2}{*}{$x^{2}$} & \multirow{2}{*}{ P-value } \\
\hline & Present & Absent & & \\
\hline \multicolumn{5}{|l|}{ BMI } \\
\hline Normal (18.5-24.9) & $2(6.9)$ & $14(26.4)$ & \multirow{4}{*}{21.89} & \multirow{4}{*}{$<0.001^{*}$} \\
\hline Pre-obese (25-29.9) & $8(27.6)$ & $31(58.5)$ & & \\
\hline Obese $(\geq 30)$ & $19(65.5)$ & $8(15.1)$ & & \\
\hline Total & $29(100.0)$ & $53(100.0)$ & & \\
\hline \multicolumn{5}{|l|}{ Smoking history } \\
\hline Present & $19(65.5)$ & $41(77.4)$ & \multirow{3}{*}{1.339} & \multirow{3}{*}{0.247} \\
\hline Absent & $10(34.5)$ & $12(22.6)$ & & \\
\hline Total & $29(100.0)$ & $53(100.0)$ & & \\
\hline
\end{tabular}

Family history of breast cancer

\begin{tabular}{|c|c|c|c|}
\hline Present & $26(89.7)$ & $45(84.9)$ & \\
\hline Absent & $3(10.3)$ & $8(15.1)$ & $0.739 f$ \\
\hline Total & $29(100.0)$ & $53(100.0)$ & \\
\hline \multicolumn{4}{|c|}{ Stage of disease } \\
\hline Stage 1 & $3(10.3)$ & $10(18.9)$ & \multirow{5}{*}{0.371} \\
\hline Stage 2 & $20(69.0)$ & $38(71.7)$ & \\
\hline Stage 3 & $4(13.8)$ & $4(7.5)$ & \\
\hline Stage 4 & $2(6.9)$ & $1(1.9)$ & \\
\hline Total & $29(100.0)$ & $53(100.0)$ & \\
\hline \multicolumn{4}{|c|}{ Level of axillary clearance } \\
\hline Level 1 & $2(6.9)$ & $9(17.0)$ & \multirow{4}{*}{$0.021 \mathrm{f}^{*}$} \\
\hline Level 2 & $19(65.5)$ & $41(77.4)$ & \\
\hline Level 3 & $8(27.6)$ & $3(5.7)$ & \\
\hline Total & $29(100.0)$ & $53(100.0)$ & \\
\hline
\end{tabular}

\section{Discussion}

Results showed that the mean age of patients was $47.01 \pm$ $10.17 \mathrm{y}$ and that comparable with Al-Mu'men in which $60 \%$ of breast cancer patients were below $50 \mathrm{y}$ and their mean age was $46.9 \mathrm{y}$ and also comparable with Al-Haris who found $65.4 \%$ of cases were not more than 50 y $[12,13] .47 .6 \%$ of breast cancer patients were overweight and $32.9 \%$ were in the obese range. Women who are who are lean have a 30-60 percent lower 
breast cancer risk than those who are overweight or obese [14-17]. Most estrogens in the body are produced in the ovaries in pre-menopause period, while in post menopause period; estrogens mostly come from fat tissue. So, overweight women have higher estrogen levels than normal weight women [18].

In the current study, $26.8 \%$ of breast cancer patients were smoker. This high percentage of smoking among female breast cancer patients may support a role for cigarette smoking in the etiology of breast cancer and highlighted the importance of timing of this exposure [19].

Regarding the family history of breast cancer, there were $13.4 \%$ of breast cancer patients had positive family history. This work is comparable with Setiawan et al. who reported positive family history as $11.1 \%$ [20]. Other study showed that $20-30 \%$ of breast cancer patients have at least one relative with a positive breast cancer history but only $5-10 \%$ of women have a detectable genetic tendency of breast cancer, so we need to do gene study to confirm hereditary breast cancer [21].

The majority of patients $(84.1 \%)$ presented with Invasive ductal carcinoma. The results were closer to that obtained by Al-Dujaily, who stated $91.1 \%$ of breast cancer histopathological diagnosis was IDC and $8.9 \%$ were ILC [22]. However, Hassan stated IDC as $96.07 \%$ and ILC as $1.96 \%$ [23].

There are several methods to prevent or reduce seroma formation, but no single method considered to be constantly effective $[24,25]$. In the current study, there was a significant reduction in the mean duration of drainage from $5.74 \mathrm{~d}$ in the non-quilting group to $4.74 \mathrm{~d}$ in the intervention group. This may due to the physical irritation of the tube drain in the control group. Many authors do not insert drain after breast surgery because they belief that the drain didn't prevent seroma and in addition to that, its associated with patients discomfort and prolongs hospitalization [26,27].

Regarding association between type of operation and study variables, there was significant association between type of operation and presence of seroma. More seroma occur among patients treated with non-quilting technique $(46.8 \%)$ in comparison to $(20 \%)$ in quilting technique $(p=0.012)$. The technique of obliteration of dead space, therefore seem to be advantageous by tacking of mastectomy flaps to the pectoralis muscle and fascia. Several authors also reported that the incidence of seroma was significantly lower in the quilting group compared with the non-quilting group [28-30].

Regarding the amount of seroma required aspiration among patients treated with both arm technique, this study was comparable with several authors who showed significantly less drainage in the quilting group when compared to the nonquilting group [28-30]. There was significant association between presence of seroma and level of clearance this may be due to removal of a larger number of lymph nodes which results in greater injury of the lymph vessels. Although this result was comparable with other authors did not report such association $[31,32]$.
Randomization and Blinding of patients are considered a major issue when studying particular variable. In the absence of randomization and masking, bias can occur and that can predispose to enthusiasm for the new procedure. Patients number in the two arms of the study were unequal which add another limitation to the study although both groups were matched and no confounding variable difference between them were present.

\section{Conclusion}

Quilting or tacking mastectomy flap to the underlying muscles and fascia to obliterate the surgical dead space is effectiveness in prevention and reduction of seroma formation.

\section{Acknowledgment}

Author is especially grateful to the College of Medicine, University of Babylon for providing all the necessary assistances, which were vital for efficacious achievement of the current effort. The author wishes to express his gratitude to the sincere contributions of the noble workers in Al-Hilla Teaching Hospital in Babylon Province, Iraq.

\section{References}

1. Parkin D. Global cancer statistics CA. Cancer J Clin 2012; 55: 74-108.

2. Ferlay J, Parkin D, Stelioarova-Foucher EG. Estimated cancer Incidence, mortality and prevalence worldwide in 2012. IARC Cancer Base 2012.

3. Koning D. Mammographic screening: Evidence from randomized controlled trials. Ann Oncol 2003; 14: 1185-1189.

4. Iraqi Cancer Registry, Iraqi Cancer Board. Results of Iraqi cancer registry 1997-2002. Iraqi Cancer Registry, Ministry of Health, Baghdad-Iraq 2002.

5. Kumar S, Lal B, Misra MC. Post-mastectomy seroma. A new look into the aetiology of an old problem. J R Coll Surg Edinb 1995; 40: 292-294.

6. Pogson CJ, Adwani A, Ebbs SR. Seroma following breast cancer surgery. Eur J Surg Oncol 2003; 29: 711-717.

7. Gong Y, Xu J, Shao J. Prevention of seroma formation after mastectomy and axillary dissection by lymph vessel ligation and dead space closure: a randomized trial. Am J Surg 2010; 200: 352-356.

8. Harada RN, Pressler VM, McNamara JJ. Fibrin glue reduces seroma formation in the rat after mastectomy. Surg Gynecol Obstet 1992; 175: 450-454.

9. O'Hea BJ, Ho MN, Petrek JA. External compression dressing versus standard dressing after axillary lymphadenectomy. Am J Surg 1999; 177: 450-453.

10. Gupta R, Pate K, Varshney S, Goddard J, Royle GT. A comparison of 5-day and 8-day drainage following mastectomy and axillary clearance. Eur J Surg Oncol 2001; 27: 26-30. 


\section{patients}

11. Shamley DR, Barker K, Simonite V, Beardshaw A. Delayed versus immediate exercises following surgery for breast cancer: a systematic review. Breast Cancer Res Treat 2005; 90: 263-271.

12. Al-Mu'men MH. Immunohistochemical study of breast carcinoma by application of Her-2/Neu and P53. Kufa Univ 2009.

13. Al-Harris ES. Pathological study of grade and stage of breast cancer by VEGF over-expression in correlation to Ki 67. Kufa Univ 2007.

14. Nelson HD, Zakher B, Cantor A. Risk factors for breast cancer for women aged 40 to 49 years: a systematic review and meta-analysis. Ann Intern Med 2012; 156: 635-648.

15. Huang Z, Hankinson SE, Colditz GA. Dual effects of weight and weight gain on breast cancer risk. JAMA 1997; 278: 1407-1411.

16. Reeves GK, Pirie K, Beral V, Green J, Spencer E, Bull D. Cancer incidence and mortality in relation to body mass index in the Million Women Study: cohort study. BMJ 2007; 335: 1134.

17. Michels KB, Terry KL, Eliassen AH, Hankinson SE, Willett WC. Adult weight change and incidence of premenopausal breast cancer. Int J Cancer 2012; 130: 902-909.

18. Key TJ, Appleby PN, Reeves GK. Circulating sex hormones and breast cancer risk factors in postmenopausal women: reanalysis of 13 studies. Br J Cancer 2011; 105: 709-722.

19. Catsburg C, Miller AB, Rohan TE. Active cigarette smoking and risk of breast cancer. Int J Cancer 2015; 136: 2204-2209.

20. Setiawan VW, Monroe KR, Wilkens LR, Kolonel LN. Breast cancer risk factors defined by estrogen and progesterone receptor status: The multi-ethnic cohort study. Am J Epidemiol 2009; 169: 1251-1259.

21. Mucci LA, Hjelmborg JB, Harris JR. Familial risk and heritability of cancer among twins in Nordic countries. JAMA 2016; 315: 68-76.

22. Al-Dujaily EA. Pathological study of breast cancer by application of epidermal growth factor receptor type II (HER-/Neu). Kufa Univ 2008.

23. Hassan AF. Immunohistochemical study of P53 overexpression in correlation to vegf in breast carcinoma. Master Sci Pathol Kufa Univ 2008.
24. Sanjitha S, Gabriel R. Seroma formation after mastectomy: pathogenesis and prevention. Indian J Surg Oncol 2010; 1: 328-333.

25. Vivek S, Somprakas B, Vijay KS. Seroma formation after breast cancer surgery: What we have learned in the last two decades. J Breast Cancer 2012; 15: 373-380.

26. Purushotham AD, McLatchie E, Young D. Randomized clinical trial of no wound drains and early discharge in the treatment of women with breast cancer. Br J Surg 2002; 89: 286-292.

27. Puttawibul P, Sangthong B, Maipang T. Mastectomy without drain at pectoral area: a randomized controlled trial. J Med Assoc Thai 2003; 86: 325-331.

28. Khater A, Elnahas W, Roshdy S. Evaluation of the quilting technique for reduction of postmastectomy seroma: A randomized controlled study. Int $\mathrm{J}$ Breast Cancer 2015.

29. Sakkary MA. The value of mastectomy flap fixation in reducing fluid drainage and seroma formation in breast cancer patients, World J Surg Oncol 2012; 10.

30. Ten BW, FJH van den W. Quilting prevents seroma formation following breast cancer surgery: closing the dead space by quilting prevents seroma following axillary lymph node dissection and mastectomy. Ann Surg Oncol 2014; 21: 802-807.

31. Gonzalez EA, Saltzstein EC, Riedner CS. Seroma formation following breast cancer surgery. Breast J 2003; 9: 385-388.

32. Hashemi E, Kaviani A, Najafi M. Seroma formation after surgery for breast cancer. World J Surg Oncol 2004; 2: 44.

\section{*Correspondence to}

Mohend A. N. Al-Shalah

Department of Surgery

College of Medicine

University of Babylon

Hilla

Iraq 